\title{
SPIRITUAL DIMENSIONS OF THE EDUCATIONAL PROCESS
}

\section{Nadiia Skotna}

\section{INTRODUCTION}

There are several reasons behind our intent to address the problem of spiritual dimensions of the educational-pedagogical space. Firstly, we continue to reflect on the fate of man in the conditions of dramatic changes that are taking place in modern civilization ${ }^{1}$. It is a very different type of civilization, the peculiarity of which is instability, a great level of dynamism in different spheres of social life, which significantly complicates the process of a personality development. With the flow of information growing rapidly, it is difficult for a man to perceive polyphony of values, worldview concepts and actions. "The world is becoming very dangerous, and at the same time it is a world which has many opportunities"2.

But we are particularly concerned about the situation of the spiritual crisis in all the spheres of human life. We are witnessing separation of people when "living human impulses, sincerity, sensitivity, either dying, or turning into wild, vulgar, primitive passions, the living human soul becomes the environment of combinatorial computing activity"3.

Unfortunately, the society, having protection against such challenges of the present in the education system as a potential condition for cultivation of the truly human qualities in a person (reasonableness, religiosity and morality), its inclusion in culture, ignores such an opportunity. We are witnessing extraordinary enthusiasm for knowledge and education, but at the same time, only the body grows in education and science, "which consists of many pieces of information, while its very soul - a system of rational principles - remains without culture and without information about itself as well as own relation to itself and own attitude to the last goals of the human person"4 . Many great scholars of the twentieth century are unanimous in that

\footnotetext{
${ }^{1}$ Скотна Н.В. Особа в розколотій цивілізації : освіта, світогляд, дії: монографія. Львів : Українські технологї, 2005. - 384 с.

${ }^{2}$ Черниговская Т. “Задача образования - научить сохранять человечность в цифровом мире” URL: https://philologist.livejournal.com/10596473.html]

3 Лимонченко В.В. Опыт философской аналитики антропологического дискурса в Православии : монографія. - Дрогобич : Видавничий відділ Дрогобицького державного педагогічного університету імені Івана Франка, 2014. - С. 8.

${ }^{4}$ Юркевич П. Д. Разум по учению Платона и опыт по учению Канта. / П. Юркевич // Философские произведения.. - М. : Правда, 1990. - С. 525.
} 
the University system is experiencing a period of "hypertrophy of means and atrophy of goals" (K. Jaspers, H.-G. Gadamer, J. Derrida, V. Lepeniz, etc.). The spiritual system is fundamentally removed from the modern education system. Undoubtedly, such tragic events as Chernobyl are terrible. But equally scary is "spiritual Chornobyl" (I. Arshavsky).

Secondly, we are concerned about ongoing reforms in the Ukrainian educational space and a focus on the Western values and ideals. Unfortunately, the spiritual experience of H. Skovoroda and V. Sukhomlinsky or representatives of the "pedagogy of cooperation" of the XX century (Sh.O. Amonoshvili, S.M Lysenkova, V.F. Shatalov, etc.) is neglected in favor of thoughtless copying of Western educational paradigms which become the basis for defining new standards and content of education. At the same time, the language stamps are repeated that "educational systems have a very serious national identity ..., there is a certain cultural context and there is our history...". We emphasize that the principles of Ukrainian education are somewhat different, more original and a purely pragmatic Western approach cannot be applied to them.

\section{Philosophical-religious principles of spiritual dimensions of the pedagogical process}

Reflections on the spiritual dimensions of educational activity highlight the philosophy of education as a special way of philosophical reflection, through which it is possible to identify new meanings in the formation and development of man in the modern civilization. Indeed, "in the functional dimension, spirituality emerges as the capacity and need for value vision, assimilation, and transformation of the world, as a means of going beyond the directly vivid existence, as an orientation to supra-personal values and meanings. Spirituality gives the human life in all its dimensions the connectedness and integrity, the defined, internally needed landmarks. Spirituality has an important existential and philosophical and categorical status as an integrative, systemic characteristic of a person, his or her life world, being in general"6. A representative of the Marburg School of NeoKantianism, the German philosopher Paul Nathorp, emphasized that pedagogy is nothing more than a concrete philosophy, which must constantly bring the creative force of its principles to the problems of human education.

\footnotetext{
${ }^{5}$ Гриневич Л. “Нова українська школа - це школа для життя у XXI столітті”

URL: https://hromadske.ua/posts/nova-ukrainska-shkola-tse-shkola-dlia-zhyttia-u-xxi-stolittiinterviu-z-ministrom-osvity-i-nauky-ukrainy

${ }^{6}$ Степаненко I. В. Духовність і душевність: категоріальні контури і функціональні можливості / І. В. Степаненко //Гуманітарний часопис - 2005. - № 1. - С. 12.
} 
We are aware that this brief overview which we offer in this section will be incomplete and fragmentary, but will nevertheless highlight the fundamental ideas and principles that are important to our study.

Greek culture plays a special role in understanding the spiritual dimensions of education and upbringing. The search for the fundamental ontological foundations of education sends us to the category of "paideia" as an organic component of ancient Greek society. Unfortunately, in the modern world paideia is often misunderstood as a universal form of learning, confirming trends in utilitarian understanding of educational tasks, methods, and functions. For modern pragmatic thinking, which has lost touch with the depth of many fundamental categories, such as "education", "upbringing", it is difficult to understand Socrates or Plato, for whom the comprehension of formative origins occurred in mental-spiritual dimensions. It was the Greeks who first introduced the system of principles of education - paideia - as a program of cultivation of the truly human features in man, introducing it into the culture, into the life of the Spirit. That program was based on the study of human nature, the awareness of the transcendent and at the same time immanent patterns that determine the physical and spiritual powers of man. There is a discovery of a person as self-sufficient value, the recognition of the right to be active and the laying on of a reasonable start. Topical are the ideas of Plato, for which education is the desire for wisdom, the help of the mind to become truly the highest Blessing (Truth, Beauty, Love) and the desire to fill human life and the world around with it.

G. Hegel paid considerable attention to the philosophical foundations of education. He was aware that the conditions for the existence of philosophy are contained in education, that is, the man's involvement in philosophy, contemplation - the ability to think. According to Hegel, a characteristic feature of man in general is that he is released from the direct and natural. "Taken in this aspect, it does not come naturally as it should be,"7 and therefore it needs education. Based on the concept of ascension to the universal, which encompasses the essential definition of the man's reason as a whole, Hegel was able to distinguish the essential in education - the general essence of consciousness is that a person makes himself in all respects a spiritual being. Thus, education as ascension to the universal is the man's main task.

According to S.Frank, spirituality is a fundamental, original characteristic of man. Everyone is eternally spiritual, but not everyone is aware of it, and not

${ }^{7}$ Гегель - Крейцеру (черновик), конец мая 1821 г. // Гегель Г. В. Ф. Работы разных лет. В 2-х т. - Т. 2. / Вильгельм Фридрих Гегель; [Сост., общ. ред. А. В. Гулыги]. - М. : Мысль, 1971. - C. 67. 
everyone consciously acts accordingly. However, only the spiritual beginning, according to the philosopher, makes a person involved in God, and only thanks to this is his true life possible: "Man feels the need for an unconditionally unwavering self-affirmative basis for his existence, and this basis is what we call God", The original idea of education in S. Frank's philosophy is important to us, which is that education is a patrimonial creative activity. In substantiating this idea, S.Frank proceeds from the fact that man does not create only external things, even if these are artistic, scientific, philosophical, theological works, not only the environment of his life, but, most importantly, man creates his own self. In other words, the subject of human creation is not only the culture in the broadest sense of the word, but also the "creation", "action" (G. Hegel) of the man himself. SL Frank says that "every kindergarten teacher is already a creator" .

I.Ilyin reveals the guidelines of spiritual education by substantiating methodological positions of understanding of the spiritual essence of the person, his soul, spiritual abilities. The philosopher emphasizes the need to find ways to unlock the spiritual faculties of man and proposes this way - to preserve the ability of heartfelt contemplation, heartfelt, spiritual love. This statement reveals an inseparable relationship between spirituality and spirituality. IO Ilyin notes: "A person who is spiritually defective since childhood can produce even a special mental image, which, when viewed superficially, can be mistaken for character and special ideas that are mistaken for "beliefs". In truth, being unprincipled and uncharacteristic, he always remains a slave to his own wicked passions, captivated by elaborate mental mechanisms that have accepted his and are omnipotent in his life, have no spiritual dimension and make a curve of his disgusting behavior. He does not resist them but disingenuously enjoys their game, forcing naive people to take their evil ability to adapt for "will", their instinctive cunning for "mind", their urge of evil passions for "feelings" 10 .

According to P. Yurkevich, religious experience reveals to us the fact that the heart is a deeper foundation of the spiritual life than the mind. The heart of a person can open and grasp, express and understand - in his own unique way - such experiences of the spirit, which by virtue of their exceptional spirituality and tenderness, distant knowledge of the mind are unattainable. The concept and distant knowledge of the mind, since it is formed by our

${ }^{8}$ Франк С. Л. Реальность и человек: метафизика человеческого бытия // Франк. С.Л. С нами Бог. М.: АСТ, 2003. - С. 286.

${ }^{9}$ Франк С. Л. Реальность и человек: метафизика человеческого бытия // Франк. С.Л. С нами Бог. М.: АСТ, 2003. - С. 347.

${ }^{10}$ Ильин И.А. О сопротивлении злу силою // Ильин И.А. Путь к очевидности. - М.: Республика, 1993. - С. 11. 
mental mood, and does not remain a distant image of external objects - is opened in the heart of man, not in the head. It must penetrate into this depth to become an active force in our spiritual life.

M. Heidegger emphasized that education and upbringing are the formation of oneself, the creation of one's own essence according to their own ontological nature. According to M. Heidegger, modern thinking is mainly instrumental in nature, since it serves primarily the field of natural sciences and technology. It is "calculative thinking", which in its own right is useful, but teaching such thinking does not lead to "humanization". In fact, modern man "flees" from thinking. Along with the development of science and technology, there is an indifference to reflections, a total thoughtlessness leading to people's beginning to deny and reject deep reflections on the sense that prevail in the world, and which, in fact, is its defining characteristic. This growing thoughtlessness is based on the process of deformation and destruction of the "inside of the modern man" subject of education from its human spiritual essence. As José Ortega y Gasset wrote in The Mission of the University, a modern specialist is a "new barbarian who has moved away from his era, archaic and primitive with respect to the horrific present and its problems. This new barbarian, in principle, is a professional who knows a lot more than ever before, but he is an engineer, a doctor, a lawyer, a scientist - and also much more cultured"12.

V.Movchan emphasizes the extra-moral orientation of modern educational technologies both in terms of the content of education and its purpose ${ }^{13}$. According to the Ukrainian scholar, a spiritual and moral component has been fundamentally removed from the European system of education; it gives only the knowledge needed to form a performer, a public servant and an employee. Having acquired certain skills, one becomes an intellectual craftsman. This problem is relevant for the Ukrainian system of education and upbringing of young people, which arose on the background of superficial interpretation of the values of Western civilization, the introduction of the idea of professionalism, competence as the most important and most important in the life and activity of man. As for spiritual and moral qualities, they are often ignored. As a result, the gap between professional training and moral status of

\footnotetext{
${ }^{11}$ Хайдеггер М. Отрешённость / М. Хайдеггер ; [пер. с нем. А.С.Солодовникова] // Хайдеггер М. Разговор на просёлочной дороге / М. Хайдеггер. - М. : Высшая школа, 1991. - C. 102.

${ }^{12}$ Ортега-и-Гассет X. Миссия университета URL: http://www.management.com.ua/vision/ vis009.html

13 Мовчан В.С. Глобалізація: до проблеми морального критерію процесу // Людинознавчі студії: Збірник наукових праць Дрогобицького державного педагогічного університету ім. І.Франка. - Дрогобич: Науково-видавничий центр ДДПУ ім. І.Франка, 2008. - C. 43-53.
} 
an individual is widening. In mass media, in special editions, most of the talk is about professional skills as the main criterion for the value of a specialist and personality whereas his spiritual essence remains unaddressed. Meanwhile, the juxtaposition of the scientifically rational and the moralspiritual is unnatural, because science and intelligence together with morality are the most important components of the spiritual world of the individual.

Reflecting on three types of pedagogy: pedagogy of formation; for pedagogy of abilities or development for the sake of development and pedagogy meaning upbringing or compassion, Batishev emphasizes that for those who associate their efforts and hopes with the system of updating educational - spiritual and civic - processes will require a third type of pedagogy. "Here, priority is given to that tier in the structure of the spiritual and spiritual world, which should be above all abilities, talents and forces, above the sphere of activity, namely - unconditional value commitment. Such a higher tier has the purpose of striving for the whole person, his whole lifedestiny, to agree with truth and beauty, goodness and community. It is the internal (conscientious) instance that directs and controls the abilities and their development. In this tier, a person finds that very co-creative attitude to the world and to himself which is a prerequisite for any creative activity, but which does not necessarily go into it. This co-creative attitude is deeper, more multidimensional and more dialectical. It contains the spiritual image of a person, his spiritual and cultural structure" $" 14$.

Such pedagogy believes that each individual is born with a huge innermost mental and spiritual potential that cannot be reduced only to evident manifestations of the personal world for us. The ideal for co-creation pedagogy is a teacher who educates on the principle: "the like causes the like, by all dimensions and levels of its personal world as a whole, because of the fullness of its openness and willingness to enter into co-involvement with own students to the end. He fills them with interests but even more so - with charisma which is always above any interests. It invites students not only to the world of cultural diversity, but also to sophisticated harmony" ${ }^{\prime 1}$. Priority should be given to the pursuit of such spiritual riches, in which the needs and interests are determined by value-semantic criteria, the dynamism of abilities - harmonization for the sake of loyalty to duty and purpose.

The unwillingness to understand and accept the spiritual foundations of education and upbringing, according to $\mathrm{V}$. Zenkovsky, leads to anthropological and pedagogical naturalism, which manifests itself in two

${ }^{14}$ Батищев Г. С. Три типа педагогики // Батищев Г. С. Избранные произведения. Алматы: Институт философии, политологии и религиоведения КН МОН РК, 2015. - С. 551.

${ }^{15}$ Батищев Г. С. Три типа педагогики // Батищев Г. С. Избранные произведения. Алматы: Институт философии, политологии и религиоведения КН МОН РК, 2015. - С. 551. 
forms - optimistic and pessimistic. In particular, "pessimistic naturalism does not only include the man in the system of mortal plain, but in no way wants to elevate him above another nature. By humiliating a person, putting him on a par with the animal world, such naturalism profanes a person"16. V. Zenkovsky was convinced that Christian anthropology, as a methodological basis, provides a new perspective for both theory and practice of pedagogy. Reflecting the complexity of the human personality, Christian anthropology is able to overcome pedagogical naturalism and return the mental and spiritual dimensions in the pedagogical space. It is impossible to understand the true essence of education and upbringing, without awareness of the essential characteristics of the image of being human - freedom, love, openness, creativity, value, uniqueness, integrity and indivisibility, catholicity, etc. "The application of the ideas of Christian anthropology to the understanding of the life of the soul and the internal dialectics of its searches is not necessary at all for one religious or even moral education, it is necessary for pedagogy as a whole. If it is true that everything is "personal" in a person, that is, everything is connected with the center of the soul, with its inner world; then it means that the ideas of Christian anthropology must either be connected with all processes of the soul or must be rejected whatsoever"17.

\section{Education and upbringing in the context of humane-personal pedagogy}

Alas, humane-personal pedagogy, "pedagogy of cooperation" did not originate in the pedagogical science, but in the practice of creatively oriented teachers. Moreover, it emerged and is increasingly becoming an alternative to authoritarian pedagogy, with its top-down approaches that have proven to be "viable" in the official pedagogical science.

Being aware of and highlighting the main aspects of the crisis of pedagogical consciousness, Sh. Amonashvili called for a change in pedagogical thinking. "The way out of the crisis is in the expansion of consciousness. Whatever conditions we define for a qualitative and perspective update of the world of education, the basis will be to change the paradigm of pedagogical consciousness. If our consciousness accepts the dimensions of spirituality, then gradually there will be a reorientation to the new values of education, to the values of humane pedagogy"18. Going beyond

16 Зеньковский B.В., Проблемы воспитания в свете христианской антропологии. URL: http://www.odinblago.ru/problemi_vospitania/

17 Зеньковский В.В., Проблемы воспитания в свете христианской антропологии. URL: http://www.odinblago.ru/problemi_vospitania/

18 Амонашвили Ш.А. Содержание и смысл гуманной педагогики. URL: http://gumanpedagog.org.ua/index.php?option=com_content $\&$ view=article\&id=4\&Itemid=15\&la $\mathrm{ng}=\mathrm{uk}$ 
the widespread definitions of humanism, Sh.Amonashvili focuses on the true essence of this concept, which reflects a person (mortal) who seeks to restore the Light, a connection with the Higher, the life of the Spirit. "The notions of spirituality and humanity are destined to change our mercantile, technocratic, materialistically concerned world, to counter the violence of the primary values - the sense of property, individualism, gluttony, the cult of utility, etc. by higher values, in the first place: faith in the higher, exalted, love for one's neighbor, conscience, service to the good"19. According to Amonashvili, the energy base of spirituality is faith, love and conscience.

The essence of the theory of humane-personal approach lies in the system of basic concepts: school, life, school of life, education, upbringing, child, mission, spirituality, development, freedom, cooperation, communication, teacher, student and lesson. The meaning of these concepts is revealed through the spiritual aspect.

According to the teachers-innovators - founders of the "pedagogy of cooperation" (Sh. Amonoshvili, S. Lysenkov, I. Ivanov, V. Shatalov, and B. Nikitina, etc.) humane pedagogy adopts the classical basis with the admonition, which leaves the possibility that the concept of spirituality, among other components, could contain the essence of a classical world religious doctrine. It is appropriate to mention Sh.Amonashvili, who emphasized pedagogical thinking as the unity of Faith and Reason. "Classical pedagogy is based on spiritual principles, on the principles of Christianity. It is worth noting that all classical pedagogy originated in the Slavic-European space, where the Christian religion has especially strong and wide roots. Height, eternity and wisdom are taken by the classical pedagogical teachings from the bowels of Christianity"20.

Therefore, as a sense of spirituality, representatives of the "pedagogy of cooperation" have assumed the assumption in three axiomatic postulates:

- reality of the Higher World, the Higher Consciousness, God;

- reality of the immortality of the human spirit and its orientation to eternal perfection;

- understanding earthly life as a segment of the path of spiritual improvement and ascension.

From these assumptions, we conclude about the philosophical perception of the child: "A child is a phenomenon, a command of the spirit in our earthly

19 Амонашвили Ш.А. Содержание и смысл гуманной педагогики. URL: http://gumanpedagog.org.ua/index.php?option=com_content \&view=article\&id=4\&Itemid=15\&la ng=uk

Амонашвили Ш.А. Содержание и смысл гуманной педагогики. URL: http://gumanpedagog.org.ua/index.php?option=com_content \&view=article\&id=4\&Itemid=15\&la $\mathrm{ng}=\mathrm{uk}$ 
life. A child carries with it his life's mission, his life's mission, which he is called to serve. A child carries the primordial energy of the spirit - unlimited opportunities for spiritual perfection. From this it follows that a child is the unity of spiritual and natural entities, the essence of the union of Heaven and Earth, Soul and Body, a unique part of the Whole, unique among unique"21. This is, according to Sh. Amonashvili, an attempt to understand the spiritual aspect of humane pedagogical thinking, the meaning of the spiritual dimension.

Through consideration of this spiritual aspect, the content of the above concepts is revealed. This concept has a spiritual and religious origin, and is thought of as the process of perfection, the descent of the soul and the formation of human spirituality. It is no accident that the religious and philosophical basis of the ideas of Sh. Amonashvili, together with the works of famous philosophers and educators, became John of the Ladder's book The Ladder of Divine Ascent ${ }^{22}$. Based on his own spiritual experience John of the Ladder tells of the Christian virtues by which man lives as a "new man", that is, he becomes like Jesus Christ - the reverend. The Ladder describes the 30 stages of spiritual growth of each Christian. At the very end of this conditional "ladder of happiness" are the three greatest virtues - Faith, Hope and Love. Of which Love is the most important. That is God.

So the School is a ladder climb, a soul lift. The bearer of the school is the teacher, that is, the teacher is the school, the school in it, not outside it. The school is also interpreted (translated from Greek) as a house of joy. But this does not negate the difficulty of climbing, because true joy can only be experienced in the process of overcoming difficulties, in the process of climbing. One can recall M. Berdyaev, who wrote that the creative path is sacrificial and painful, but it is always a release from any oppression.

The system of humane-personal approach inspires the teacher to create such an educational process in which the Child in the life itself learns to change, improve, improve the conditions of this life, improve its quality, and not adapt to the already formed conditions. "Collaborative pedagogy (it is about the practices of well-known Soviet educators-innovators) was based on involving students in a common cause, so that it became important for each of them as a personal problem and therefore interesting, fascinating. Such a pedagogical space is a space of personal communication, which, in turn, forms the basis for the development of subjects in the sphere of joint

21 Амонашвили Ш.А. Содержание и смысл гуманной педагогики. URL: http://gumanpedagog.org.ua/index.php?option=com_content \&view=article\&id=4\&Itemid=15\&la $\mathrm{ng}=\mathrm{uk}$

22 Лествичник Иоанн, преподобный. Лествица или Скрижали духовные. URL: https://azbyka.ru/otechnik/Ioann_Lestvichnik/lestvitsa-ili-skrizhali-dukhovnye/ 
activity ... That is why the subject of study is no longer perceived as remote and abstract but acquires a concrete embodiment of living meanings addressed to the subjectivity of everyone ${ }^{\text {"23 }}$.

The concept of the School of Life, which is called the name of the school of humane-personal orientation, embraces exactly this meaning. Hence the principle that underlies the educational process in the School of Life: to develop and nurture life in the child through life itself.

In the context of the pedagogy of cooperation education is understood as the nourishment of the spiritual-spiritual axis of the individual. That is, there should be an ascent at the school, the formation of the very main thing in a person, which comprises the whole essence of his personality - soul and spirituality as universal. Such an ascent must be in advance of knowledge, ennoble it, and thus enlighten the mind. Spiritualized mind is a mind open to the encounter with a graceful Divine beginning, which enables creativity as a realization of man's divine beginning in all empirical, natural reality, man's realization of divine forces in the very real being of nature. Franciscus Assisiensis believed that there was no such knowledge that could lead to harmony. Another power, a different culture, leads a person to harmony - a culture of the heart! P. Florensky calls a man whose mind and heart are united by the energy of love. "The mind longs for love same as the heart, and blossoms only on reaching it. This is the secret of "love begets knowledge" or "knowledge is made by love" 24 . Love is the highest sense of our soul, the main sense of nature, the ultimate sense of divine. Without love there is no complete understanding; and one can prove that a wise man of excellent mind, but with a cold, unloved soul, is not a sorcerer of fruitful wisdom (M. Maksymovich). Verily, the living wisdom of the mind is established in love!

Education is not a molding of a person without the participation of the person who walks the path of development, adulthood and freedom. Education is the process of bringing the soul and heart of the child into the image of all the best (highest, spiritualized) heritage of human culture. "Everything what the participants in the pedagogical process (in other words, the content of education) talk about - in this way or another is a culture: all this is produced by humanity and passed on to the next generations as a gift... for meaningful and creative

23 Возняк В.С. Ситуація учнівство/учительство як вища форма розвитку взагалі // Феномен учнівства та учительства в історії філософії та культури (Тези Міжнародної наукової конференції "XXV Читання, присвячені 75-й річниці з дня смерті засновника Львівсько-Варшавсьвої філософської школи К .Твардовського”, 11-12 лютого 2013 року) / Відп. ред. В.Л. Петрушенко, редагування В.Л. Петрушенко, І.В. Карівець. - Львів : Вид-во “Ліга-Прес", 2013. - С. 96.

${ }^{24}$ Флоренский П.А.: Pro et contra: Личность и творчество Павла Флоренского в оценке pус. мыслителей и исследователей: Антология / Сост., вступ. ст., примеч. и библиогр. К.Г. Исупов. - СПб.: РХГИ, 1996. - С. 138. 
continuation, development - and above all - development into their subjectivity, into the subjectivity of everyone, into the individuality, subjective uniqueness. Transforming the content of education into culture in the full and true sense of the word ... the essence of the process of humanitarization of education ... And the most difficult and most important task of the teacher is to activate the subjectivity of culture so that it is taught and nurtured - in the sense of: animating by itself the soul, heart and mind of every pupil" 25 .

According to Sh.Amonashvili, the concept of the Teacher has the following semantic basis: the Spirit which creates, radiates and gives Light, Life (meaning of Life), Love, Knowledge, Wisdom. The terms Teacher and pupil contain the highest spiritual content, which has the same source as the basic concepts for humane pedagogy: School, Upbringing, Education, Enlightenment, Lesson and Life. The teacher and the pupil are the main general concepts; everyone else is grouped around and serves them.

Besides, this integrity of the concept of the Teacher-pupil, the whole palette of enclosed in profound allegorical formulas interdependence is revealed to us by the New Testament: "I planted, Apollos watered, but God gave the increase. So then neither he who plants is anything, nor he who waters, but God who gives the increase. Now he who plants and he who waters are one, and each one will receive his own reward according to his own labor. For we are Gods fellow workers; you are Gods field, you are Gods building."(1 Cor. 3: 6-9). The Teacher is the mediator between God and the infant soul. And if he does not plant and water with a feeling and understanding of deep responsibility and the same deep knowledge and creativity - how and when to water and nurture - then the grain of the spirit will not get the necessary development, the life and destiny of the child will be distorted, his mission will be distorted.

Thus, humane-personal pedagogy accepts the child as he is, sees the infinity of the child, realizes its cosmic nature, and leads, prepares it for service to the Universal. The co-authors of the Manifesto of Humane Pedagogy emphasize that the renewal of the educational process is that "every Child ought to be brought up by a Noble and Generous Person, develop spiritually and morally, master knowledge, which enhances his/her consciousness and leads to creativity and creation of good, learn to express, protect and affirm his/her free will in life, love for Motherland, appreciate and carefully treat the centuries-old culture of own people and humanity" ${ }^{\text {,2 }}$. The

${ }^{25}$ Возняк В. С. Культура як “третій суб’єкт” освітнього процесу // Проблеми гуманітарних наук. : збірник наукових праць Дрогобицького державного педагогічного університету імені Івана Франка / Ред. кол. Н. Скотна (головний редактор), О. Ткаченко (редактор розділу) та ін. Дрогобич : Вид. відділ ДДПУ імені Івана Франка, 2014. - Вип. 23. Філософія. - С. 20.

26 Маніфест гуманної педагогіки URL: http://gumanpedagog.org.ua/index.php?id= $127 \&$ Itemid=63\&lang=uk\&option=com_content $\&$ view=article 
goals and objectives of this higher form of pedagogical thinking are related to the creation of a refined person. Humane pedagogical thinking seeks to embrace the boundless and this is the power of educational systems and processes born in their depths.

In this context, very relevant are the peculiarities of Ukrainian education and upbringing, which in the humanistic sense enrich the world culture with a variety of national colors. And it magnifies a person who self-identifies with his or her tradition and parental customs and is at the same time open to the perception of the world culture.

We argue that under any circumstances, upbringing should be based on the principle of civic consent, understanding and cooperation of people, regardless of their ethnicity, religious beliefs, etc. It denies the confrontation of a man with another man, social groups, ethnic communities or denominations; is tolerant and engages in dialogue both within Ukrainian society and internationally. The establishment of the Ukrainian non-conflict lifestyle through education in the spirit of tolerance as an internal orientation and an active position of self-restraint, non-interference through manipulation into the spiritual world of the individual is a key task of the present which faces the national education, upbringing and political system of the society. Only this approach, according to the author, corresponds to a civilizational educational strategy that combines the positive features of pedagogues of traditional Eastern and anthropogenic Western civilizations, using national Ukrainian heritage in the fields of education and upbringing.

\section{CONCLUSIONS}

For a country seeking to become an active subject of international educational life, an important task is to understand not only its own educational and cultural tradition and to present to the world community its importance and importance, but also to update the educational space based on an understanding of the ontological nature of the phenomenon of education with its special feature - spiritual vector. And perhaps the most important task of education is to teach children "to use knowledge for their own individual and professional tasks" 27 .

In our opinion, the desire to help children to learn how to retain and preserve humanity in a globalized, digital world, and to expand the boundaries of internal freedom, must always remain paramount. And the ideal result of education and upbringing is "a person with a broad outlook who can make a principled stands, incorruptible and fearless, open and faithful, reliable and

${ }^{27}$ Гриневич Л. “Нова українська школа - це школа для життя у XXI столітті” URL: https://hromadske.ua/posts/nova-ukrainska-shkola-tse-shkola-dlia-zhyttia-u-xxi-stolitti-interviu-zministrom-osvity-i-nauky-ukrainy 
all-encompassing conscience of the whole world, who is able to measure his actions and his development in accordance with his value and sense justification, remembering how important is to be worthy of one's strength and talents" 28 .

This can be done only at the level of philosophical pedagogical thinking, which is aware of the ontological essence of human being in the dimensions of freedom, love, openness, creativity, intrinsic value, uniqueness, integrity and indivisibility, catholicity, etc. And the educational-pedagogical process is built on the basis of unconditional priority of spiritual and spiritual dimensions over object-organizational "factors". An example of such thinking is the spiritual experience of the founders and followers of humane-personality pedagogy, "pedagogy of collaboration", in educational institutions of which there is an ascension, the formation of the very main thing in man, which is the whole essence of his personality - soul and spirituality as the universal.

We emphasize that modern education is designed to help people learn to cognite, learn to make, learn to live and learn to live together. A paradoxical situation arises: life itself and its tasks are complicated and the education system is simplified. Ukraine is facing problems, the essence of which boils down not only to the adoption (or non-acceptance) of certain principles of the functioning of the educational system and its restructuring, the implementation of not only organizational and structural changes, but also the need for changes in thinking, mentality, system of attitudes and values. In order not to get lost in the big world, there are some strategies that require, first and foremost, multicultural education. It must be developed in two directions: knowledge and respect for all existing cultural systems and the possession of a personal culture born out of the synthesis of the national, civic, civilizational culture of the social environment.

\section{SUMMARY}

The proposed materials emphasize that the current crisis in education and the spiritual crisis in general actualize the need for philosophical and pedagogical comprehension of the spiritual dimensions of the educational process. It is proved that only such level of pedagogical thinking can overcome anthropological and pedagogical naturalism. This is clearly expressed in the practice of "pedagogy of collaboration", whose representatives understood the educational process as nourishing the spiritual-spiritual axis of the personality. Observing the ongoing reforms in the educational field, the author states that the education system should be an area free of unnecessary constant experiments. It implies tradition. In this

28 Батищев Г.С. Три типа педагогики //Батищев Г. С. Избранные произведения. Алматы: Институт философии, политологии и религиоведения КН МОН РК, 2015. - С. 552. 
context, Sh.Amonashvili's idea that classical pedagogy has always been based on spiritual principles and on Christianity in particular becomes very relevant today. The author emphasizes that affirmation of the Ukrainian non-conflict way of life through education in the spirit of tolerance as an internal orientation and an active position of self-restraint, non-interference through manipulation into the spiritual world of the individual is a key task of the present, which confronts the national education, upbringing and political system of the society.

\section{REFERENCES}

1. Амонашвили Ш.А. Содержание и смысл гуманной педагогики. URL: http://gumanpedagog.org.ua/index.php?option=com_content\&view= article\&id $=4 \&$ Itemid $=15 \&$ lang $=\mathrm{uk}$

2. Батищев Г.С. Три типа педагогики // Батищев Г.С. Избранные произведения. - Алматы: Институт философии, политологии и религиоведения КН МОН РК, 2015. - С. 546-554.

3. Возняк В.С. Культура як “третій суб'єкт” освітнього процесу // Проблеми гуманітарних наук. : збірник наукових праць Дрогобицького державного педагогічного університету імені Івана Франка / Ред. кол. Н. Скотна (головний редактор), О. Ткаченко (редактор розділу) та ін. Дрогобич : Вид. відділ ДДПУ імені Івана Франка, 2014. - Вип. 23. Філософія. - С. 14-28.

4. Возняк В.С. Ситуація учнівство/учительство як вища форма розвитку взагалі // Феномен учнівства та учительства в історії філософії та культури (Тези Міжнародної наукової конференції "XXV Читання, присвячені 75-й річниці з дня смерті засновника Львівсько-Варшавсьвої філософської школи К .Твардовського", 11-12 лютого 2013 року) / Відп. ред. В.Л. Петрушенко, редагування В.Л. Петрушенко, І. В. Карівець. Львів : Вид-во “Ліга-Прес", 2013. - С. 94-98.

5. Гегель - Крейцеру (черновик), конец мая 1821 г. // Гегель Г.В.Ф. Работы разных лет. В 2-х т. - Т. 2. / Вильгельм Фридрих Гегель; [ Сост., общ. ред. А.В. Гулыги]. - М. : Мысль, 1971. - 630 с.

6. Гриневич Л. "Нова українська школа - це школа для життя у XXI столітті" URL: https://hromadske.ua/posts/nova-ukrainska-shkola-tseshkola-dlia-zhyttia-u-xxi-stolitti-interviu-z-ministrom-osvity-i-nauky-ukrainy

7. Зеньковский В.В., Проблемы воспитания в свете христианской антропологии. URL: http://www.odinblago.ru/problemi_vospitania/

8. Ильин И.А. О сопротивлении злу силою // Ильин И.А. Путь к очевидности. - М.: Республика, 1993. - С. 6-133.

9. Лествичник Иоанн, преподобный. Лествица или Скрижали духовные. URL: https://azbyka.ru/otechnik/Ioann_Lestvichnik/lestvitsa-iliskrizhali-dukhovnye/ 
10. Лимонченко В.В. Опыт философской аналитики антропологического дискурса в Православии : монографія. - Дрогобич : Видавничий відділ Дрогобицького державного педагогічного університету імені Івана Франка, 2014. - 475 с.

11. Маніфест гуманної педагогіки URL: http://gumanpedagog.org.ua/ index.php?id=127\&Itemid=63\&lang=uk\&option=com_content $\& v i e w=$ article

12. Мовчан В.С. Глобалізація: до проблеми морального критерію процесу // Людинознавчі студії: Збірник наукових праць Дрогобицького державного педагогічного університету ім. І. Франка. - Дрогобич: Науково-видавничий центр ДДПУ ім. І.Франка, 2008. - С. 43-53.

13. Ортега-и-Гассет X. Миссия университета URL: http://www.management.com.ua/vision/vis009.html

14. Скотна Н.В. Особа в розколотій цивілізації : освіта, світогляд, дії: монографія. - Львів : Українські технологї, 2005. - 384 с.

15. Степаненко I.В. Духовність і душевність: категоріальні контури і функціональні можливості / І.В. Степаненко // Гуманітарний часопис 2005. - № 1. - С. 5-12.

16. Флоренский П.А.: Pro et contra: Личность и творчество Павла Флоренского в оценке рус. мыслителей и исследователей: Антология / Сост., вступ. ст., примеч. и библиогр. К.Г. Исупов. - СПб.: РХГИ, 1996. $-752 \mathrm{c}$.

17. Франк С.Л. Реальность и человек: метафизика человеческого бытия // Франк. С.Л. С нами Бог. М.: АСТ, 2003. - С. 133-436.

18. Хайдеггер М. Отрешённость / М. Хайдеггер ; [пер. с нем. А.С. Солодовникова] // Хайдеггер М. Разговор на просёлочной дороге / М. Хайдеггер. - М. : Высшая школа, 1991. - С. 102-111.

19. Черниговская Т. “Задача образования - научить сохранять человечность в цифровом мире”. URL: https://philologist.livejournal.com/ 10596473.html

20. Юркевич П.Д. Разум по учению Платона и опыт по учению Канта. / П. Юркевич // Философские произведения.. - М. : Правда, 1990. - C. 466-526.

\section{Information about the author: \\ Nadiia Skotna,}

Doctor of Philosophical Sciences, Professor, Rector, Drohobych Ivan Franko State Pedagogical University 24, Ivan Franko str., Drohobych, 82100, Ukraine ORCID: https://orcid.org/0000-0002-2929-8926 